\title{
Metode Trigger Detection Untuk Gerakan Kendaraan NPC Dalam Game
}

\author{
Wandah Wibawanto \\ Program Studi Desain Komunikasi Visual, Jurusan Seni Rupa, \\ Fakultas Bahasa dan Seni, Universitas Negeri Semarang \\ e-mail: wandah@mail.unnes.ac.id
}

\begin{abstract}
Abstrak
Artikel ini membahas tentang penggunaan metode trigger detection untuk membuat simulasi lalulintas yang melibatkan kendaraan NPC (Non Playable Character) untuk keperluan game. Dalam sebuah game bertipe racing atau open world seperti Need For Speed, Grand Theft Auto, Watch Dog dan sejenisnya, simulasi kendaraan NPC diperlukan untuk menghasilkan kesan realistis. Dalam membuat alogaritma gerakan kendaraan NPC pada umumnya digunakan metode pathfinding dan metode waypoint. Alternatif yang dapat digunakan adalah metode trigger detection, yaitu dengan menempatkan sejumlah sensor di sekeliling kendaraan. Selanjutnya sensor akan mendeteksi tumbukan antara sensor dengan objek yang berada di lingkungan virtual dalam game. Hasil dari tumbukan tersebut diolah lebih lanjut melalui proses posisi, deteksi, reaksi dan negosiasi agar menghasilkan gerakan yang dinamis. Metode ini selanjutnya diujicoba untuk mengetahui keefektifannya.
\end{abstract}

Kata kunci: algoritma, kendaraan NPC, metode trigger detection.

\begin{abstract}
Abstrak
This article discusses the use of trigger detection method to simulate traffic involving vehicles NPCS (Non-Playable Character) for the game. In a game of racing or open world like Need For Speed, Grand Theft Auto, Watch Dog and the like, simulating vehicle NPC required to produce a realistic impression. In making the complex algorithms of vehicle motion used method of NPC pathfinding and waypoint method. An alternative that can be used is the method of trigger detection, ie by placing a number of sensors around the vehicle. The next sensor will detect the collision between the sensor and the objects that are in the virtual environments in the game. The result of the collision the further process of reaction, detection, positioning and negotiating in order to generate a dynamic movement. These methods are further tested to know their effectiveness.
\end{abstract}

Keywords: algorithm, vehicle NPC, trigger detection 